\title{
POR QUE O PORTUGUÊS NÃO VEIO DO LATIM?: UMA ANÁLISE HISTORIOGRÁFICA DA GRAMÁTICA PEDAGÓGICA DO PORTUGUÊS BRASILEIRO
}

\author{
Why did not portuguese originate from latin? A \\ historiographic analysis of "Gramática pedagógica do \\ português brasileiro"
}

\author{
Marcelo Alessandro Limeira dos ANJOS ${ }^{41}$ \\ Meryane Sousa OLIVEIRA ${ }^{42}$
}

Resumo | Este trabalho visa analisar o tratamento dispensado à origem histórica da língua portuguesa na Gramática Pedagógica do Português Brasileiro (doravante GPPB), de autoria de Marcos Bagno (2011). $O$ objetivo geral é averiguar, na obra, o tratamento dado pelo autor à origem da língua portuguesa, contrapondo-o à perspectiva adotada por autores brasileiros que fizeram algum tipo de Linguística Histórica e aos dados verificados nas demais produções do autor. Para tanto, foram analisadas informações trazidas nos materiais que serviram de fontes para a pesquisa, sobretudo quanto à retórica do autor, a fim de perceber as prováveis razões para o afastamento ou aproximação dele à tese da origem latina do português. Para a análise, utilizou-se a proposta teórico-metodológica de Koerner (2014) e a proposta desenvolvida por Bastos e Palma (2008) sobre a investigação de objetos contemporâneos relacionados a uma perspectiva historiográfica. As análises apontam para continuidades e descontinuidades no tratamento da história da língua portuguesa que podem ser consideradas a partir da retórica adotada pelo autor em diferentes obras. É possível, pois, destacar que Bagno, na $G P P B$, apresenta uma retórica aparentemente descontinuísta com relação aos estudos histórico-linguísticos tradicionais, uma vez que, no restante de suas obras, inclusive nas posteriores à $G P P B$, sobressai-se um discurso continuísta em relação à tradição.

Palavras-chave | Historiografia Linguística. Gramática brasileira. Origem do português.
Abstract | This paper proposes to analyze the treatment given to the historical origin of the Portuguese language in the Gramática pedagógica do português brasileiro, by Marcos Bagno (2011). The general objective is to verify the treatment given by the author to the origin of the Portuguese language, in the referred grammar, opposing it to the perspective adopted by Brazilian authors who addressed some type of Historical Linguistics and to the verified data in the other author's productions. For this purpose, we analyzed the information presented in the materials that served as sources for the research, especially in relation to the author's rhetoric, in order to perceive the probable reasons for the author's distance or his approach to the thesis about the Latin origin of Portuguese.For the analysis, it was taken into account the theoretical-methodological proposal of Koerner (2014) and the proposal developed by Bastos and Palma (2008) on the investigation of contemporary objects related to a historiographical perspective.The analyses point to continuities and discontinuities in the treatment of the Portuguese language history that can be considered from the rhetoric adopted by the author in different works. It is possible, therefore, to emphasize that Bagno, in the GPPB, presents an apparently discontinuous rhetoric in relation to the traditional historical-linguistic studies, while in his remaining works, a continuous discourse in relation to tradition stands out.

Keywords | Linguistic Historiography. Brazilian grammar. Origin of Portuguese.

41 Anjos. UFPI. Endereço eletrônico: marcelodosanjos@ufpi.edu.br. ORCID ID: https://orcid.org/00000003-4626-053X

42 Oliveira. UFPI. Endereço eletrônico: meryaneoliveira@yahoo.com.br. ORCID ID: https://orcid.org/00000002-8267-1646 
- Por que o português não veio do latim?: Uma análise historiográfica da Gramática Pedagógica do Português Brasileiro

\section{Introdução}

O século XXI está sendo bastante produtivo quando se trata da elaboração e publicação de gramáticas de língua portuguesa que, de algum modo, se afastam do que Vieira (2015) denominou de Paradigma Tradicional de Gramatização (PTG). Faraco e Vieira (2016) apresentam boa parte dessas obras, ressaltando suas principais características e discutindo o panorama contemporâneo dessas produções. As gramáticas contemporâneas, como comprovam os autores, são bastante heterogêneas e tais características podem estar ligadas ao conteúdo das obras, ao público ao qual se destinam e às diversas diretrizes teóricas e metodológicas às quais as correntes de pensamento estão filiadas.

Desse modo, tem-se acesso, hoje, a uma quantidade representativa não só de gramáticas, mas de dissertações, teses, artigos etc. sobre especificidades da língua portuguesa, materiais que promovem um campo profícuo para a discussão de variados aspectos, tais como: nomenclaturas, classificação, história sociopolítica, só para citar alguns. Vieira (2015) denomina alguns desses compêndios de Gramáticas Contemporâneas do Português Brasileiro $(G C P B)$ e, dentre as várias obras que ganham representatividade nesse segmento, destaca-se, para os fins deste artigo, a GPPB, de autoria de Marcos Bagno, publicada no ano de $2011^{43}$, especificamente no que diz respeito aos aspectos sócio-históricos e linguísticos que envolvem a questão da origem histórica do português, pontualmente discutida na respectiva obra.

A $G P P B$ é uma recente publicação que descreve diversas tendências hoje presentes no cenário brasileiro, dentre elas: a realidade linguística do Brasil; aspectos epistemológicos; históricos; gramaticais etc. Com isso, a história da origem da língua portuguesa adquire representatividade na $G P P B$ por seu papel revelador de determinada perspectiva assumida pelo autor da gramática, além de trazer informações sobre a natureza dessa língua.

Diante disso, este artigo analisa o tratamento dado pelo autor ao aspecto da língua supracitado, comparando a proposta trazida por Bagno, na $G P P B$, fonte primária da pesquisa, com o corpus secundário aqui selecionado, dez textos de autores que fizeram algum tipo de Linguística Histórica ${ }^{44}$, além de doze textos da produção linguística de Bagno, que reforçam a posição dos autores sobre a origem latina da língua portuguesa. Essa discussão vale-se, pois, do aparato teórico-metodológico da Historiografia

\footnotetext{
43 Vieira (2015) apresenta o ano de 2012 como sendo o ano da primeira edição da GPPB, no entanto, a referida gramática foi editada no ano de 2011, como consta em sua ficha catalográfica. O próprio Vieira reconhece, em sua tese, que "A obra foi finalizada em 2011, mas lançada no mercado em janeiro de 2012 [...]" (VIEIRA, 2015, p. 342). Assim, segue-se, em todo o texto, a referência de 2011.

44 Os autores selecionados para compor as fontes secundárias deste artigo não foram escolhidos de forma aleatória. Buscou-se, para o limite deste texto, contemplar tanto autores considerados clássicos no âmbito dos estudos linguístico-filológicos, quanto aqueles com produção mais recente, de modo que restasse clara a manutenção da tese que filia a origem do português ao latim vulgar.
} 
Linguística (doravante, $\mathrm{HL}$ ), especificamente no que se refere aos princípios que regulam a investigação de objetos contemporâneos relacionados a uma perspectiva historiográfica.

Para tanto, na seção 1, será feito um apanhado histórico do que os autores/ gramáticos dizem a respeito da origem da língua portuguesa. Em seguida, na seção 2, serão apresentadas as considerações ou resultados da análise feitos nas obras, caracterizando, além disso, os aspectos teórico-metodológicos que nortearam a pesquisa e, por fim, na última seção, considerações finais, buscar-se-á demonstrar como a GPPB dialoga com a tradição.

\section{A herança greco-latina e a tradição gramatical}

O ponto de partida que culminará na análise apresentada nas próximas seções é a ideia já difundida por alguns autores, dentre eles, Vieira (2015), de que as novas gramáticas produzidas nesse início de século promovem movimentos de ruptura com relação ao já mencionado $P T G$. Para o referido autor, o $P T G$ origina-se de ramificações dos estudos linguísticos que, por sua vez, têm origem na filosofia grega clássica, a qual se tornou "o mentor teórico-metodológico e socioideológico do que tradicionalmente vem se entendendo por gramática desde os gramáticos alexandrinos da Antiguidade aos gramáticos normativos brasileiros de hoje" (VIEIRA, 2016, p. 21, grifos do autor). Assim, tanto no que diz respeito à estrutura, quanto ao conteúdo, esses novos compêndios gramaticais, independentemente de quem os produziu, apresentam traços que caracterizam esses trabalhos como fazendo parte de um gênero específico, denominado e reconhecido pela tradição como gramática, mas, apesar disso, inauguram um novo modo de analisar e discutir questões relacionadas à língua portuguesa.

Antes, porém, de iniciar a análise e discussão dos dados, é preciso estabelecer uma breve história do pensamento gramatical, mantendo como referencial teórico as diretrizes propostas por Koerner (2014). Além disso, cumpre reconstruir brevemente o clima de opinião que favoreceu a produção da obra analisada, a relação existente entre a história externa e a história interna, os argumentos usados pelos autores etc.

Muitos autores remetem o surgimento do gênero textual "gramática" à antiguidade clássica. Os primeiros filósofos e gramáticos da história ocidental desenvolveram estudos baseados na filosofia grega clássica que, com o passar do tempo, foram se ramificando e estabelecendo um modelo teórico-metodológico do que tradicionalmente se entende por gramática. Segundo Borges Neto (2016, p. 267), “O texto gramatical mais antigo que conhecemos foi escrito por Dionísio Trácio, filósofo ligado à Biblioteca de Alexandria, por volta do ano 100 a. $C^{\prime \prime}$ e, apesar de dúvidas que ainda persistem sobre a autoria e a datação da obra, o mesmo autor afirma que o texto é tomado como o iniciador dos estudos gramaticais (op. cit., p. 267). 
- Por que o português não veio do latim?: Uma análise historiográfica da Gramática Pedagógica do Português Brasileiro

Ainda com Borges Neto, o texto de Dionísio (Tékhnē Grammatikē) influenciou não só no modo de organização dos conteúdos dos textos gramaticais, como também determinou fortemente sua finalidade (op. cit., p. 268), portanto, é possível verificar, na maioria das gramáticas produzidas desde o período clássico até gramáticas produzidas hodiernamente, uma forte aproximação com o formato padrão desenvolvido pelos gregos e, posteriormente, reproduzido e propagado pelos latinos.

Entretanto, ao considerar estudos gramaticográficos do português brasileiro do século XXI, põe-se em evidência a produção de gramáticas que, em linhas gerais, não seguem pari passu esse modelo de gramática que ficou conhecido como "greco-latino". Tal percepção, de mudança na gramaticografia brasileira, vem de obras produzidas e publicadas, principalmente, sobre gramáticas contemporâneas de referência ${ }^{45}$.

Aspectos distintos das gramáticas contemporâneas já foram analisados por especialistas da área. Destacam-se, nesse sentido, obras como: Gramáticas contemporâneas do português: com a palavra, os autores (2014) e Gramáticas brasileiras: com a palavra, os leitores (2016) em que, além de análises internas das obras, têm-se uma visão geral de que o final do século XX e o início do século XXI "inauguram" um período em que são produzidas gramáticas que inovam no que tange à apresentação, descrição e análise de categorias linguísticas.

Do final do século XX ao início do século XXI, foram produzidas oito gramáticas do português escritas por autores brasileiros e publicadas no Brasil. As primeiras gramáticas de base linguística foram gradativamente surgindo e estabelecendo um contexto oportuno para a produção de outras gramáticas contemporâneas. No que concerne a essa produção, segue uma lista dessas gramáticas, elaborada a partir dos trabalhos de Neves e Casseb-Galvão (2014), Vieira (2015) e Faraco e Vieira (2016), cronologicamente sumarizadas na tabela abaixo:

\footnotetext{
45 De acordo com Leite (2014), denominam-se gramáticas contemporâneas de referência as gramáticas de base linguística, publicadas a partir de 1980, cujos autores trazem em seus instrumentos linguísticos (Auroux, 1998) estudos sobre a evolução dos conceitos relacionados às categorias linguísticas em que se sobressaem terminologias, conceitos advindos da linguística clássica e em que são utilizadas diversas teorias que fundamentam a reconstrução de conceitos tradicionais.
} 


\begin{tabular}{|c|c|c|c|}
\hline Obra & Autor & Edição/ano & Local/editora \\
\hline $\begin{array}{l}\text { Moderna Gramática } \\
\text { Portuguesa }\end{array}$ & Evanildo Bechara & $37^{\mathrm{a}}$ ed., 1999 & $\begin{array}{l}\text { Rio de } \\
\text { Janeiro/ } \\
\text { Nova } \\
\text { Fronteira }\end{array}$ \\
\hline $\begin{array}{l}\text { Gramática de usos do } \\
\text { português }\end{array}$ & $\begin{array}{l}\text { Maria Helena de } \\
\text { Moura Neves }\end{array}$ & $1^{\mathrm{a}}$ ed., 2000 & $\begin{array}{l}\text { São Paulo/ } \\
\text { Editora } \\
\text { UNESP }\end{array}$ \\
\hline $\begin{array}{l}\text { Gramática Houaiss da } \\
\text { Língua Portuguesa }\end{array}$ & $\begin{array}{l}\text { José Carlos de } \\
\text { Azeredo }\end{array}$ & $1^{\mathrm{a}}$ ed., 2008 & $\begin{array}{l}\text { São Paulo/ } \\
\text { Publifolha }\end{array}$ \\
\hline $\begin{array}{l}\text { Gramática do brasileiro: } \\
\text { uma nova forma de } \\
\text { entender a nossa língua }\end{array}$ & $\begin{array}{l}\text { Celso Ferrarezi Jr. \& } \\
\text { Iara M. Teles }\end{array}$ & $1^{\mathrm{a}}$ ed., 2008 & $\begin{array}{l}\text { São Paulo/ } \\
\text { Globo }\end{array}$ \\
\hline $\begin{array}{l}\text { Gramática do Português } \\
\text { Brasileiro }\end{array}$ & Mário A. Perini & $1^{\mathrm{a}}$ ed., 2010 & $\begin{array}{l}\text { São Paulo/ } \\
\text { Parábola } \\
\text { Editorial }\end{array}$ \\
\hline $\begin{array}{l}\text { Nova Gramática do } \\
\text { Português Brasileiro }\end{array}$ & $\begin{array}{l}\text { Ataliba Teixeira de } \\
\text { Castilho }\end{array}$ & $1^{\mathrm{a}}$ ed., 2010 & $\begin{array}{l}\text { São Paulo/ } \\
\text { Contexto }\end{array}$ \\
\hline $\begin{array}{l}\text { Gramática Pedagógica } \\
\text { do Português Brasileiro }\end{array}$ & Marcos Bagno & $1^{\mathrm{a}}$ ed., 2011 & $\begin{array}{l}\text { São Paulo/ } \\
\text { Parábola } \\
\text { Editorial }\end{array}$ \\
\hline $\begin{array}{l}\text { Gramática da língua } \\
\text { portuguesa padrão }\end{array}$ & Amini Boainain Hauy & $1^{\mathrm{a}}$ ed., 2014 & $\begin{array}{l}\text { São Paulo/ } \\
\text { EDUSP }\end{array}$ \\
\hline
\end{tabular}

Tabela 1 - Gramáticas brasileiras contemporâneas do século XXI ${ }^{46}$ Fonte: Elaboração própria

A crítica à doutrina gramatical tradicional, de acordo com Vieira (2016), começou no meio acadêmico a partir da década de 1960 e resultou na produção de gramáticas brasileiras contemporâneas que seguem novas perspectivas teóricas. Para o autor, as gramáticas brasileiras contemporâneas são resultados de "um cenário epistemológico próprio, um 'estado de espírito acadêmico'" (op. cit., p. 36), isto é, as características

46 A Moderna Gramática Portuguesa, de Evanildo Bechara, publicada pela primeira vez em 1961, compõe a tabela, com a $37^{a}$ ed., por ser a referida edição de 1999, nas palavras de Mulinacci (2016, p. 114), "uma espécie de emblemático divisor de águas da tradição gramatical brasileira". Esta obra, portanto, apresenta-se como um "novo livro" em comparação com as edições anteriores. 
- Por que o português não veio do latim?: Uma análise historiográfica da Gramática Pedagógica do Português Brasileiro

inerentes a essas gramáticas, que se afastam em alguma medida do modelo greco-latino, são consequências de um cenário construído por autores, linguistas/gramáticos, que, ao se preocuparem com os fenômenos da língua, criaram um contexto propiciador para o surgimento dessas gramáticas, dentre elas, a que serve de corpus a esta pesquisa, a GPPB.

Leite (2014), contudo, considera que, embora se verifiquem novidades quanto à composição ou estrutura dessas gramáticas produzidas contemporaneamente, ainda assim, elas mantêm características inerentes ao gênero "gramática" e afirma que:

É possível verificar que mesmo gramáticas muito diferentes entre si podem guardar similitudes no que tange à apresentação, descrição e interpretação das categorias linguísticas. Como cabe ao historiador acompanhar o desenvolvimento das ideias linguísticas, o estudo da evolução dos conceitos é tarefa essencial (LEITE, 2014, p. 118).

A GPPB e todas as outras obras listadas na tabela 1, ao que parece, apresentam-se como obras inovadoras em vários aspectos e marcam um momento crucial no percurso da gramaticografia brasileira contemporânea.

Tem-se, pois, no cenário contemporâneo, uma conjuntura favorável ao desenvolvimento de gramáticas brasileiras de referência que, de algum modo, representam certa "ruptura" com a tradição de gramáticas do português. Tais gramáticas ilustram as transformações pelas quais passaram, nos últimos anos, os estudos relacionados à produção gramaticográfica brasileira e refletem externamente o clima de opinião da época em que foram produzidas.

Dito isso, será analisado, no próximo tópico, considerando os propósitos e os limites deste artigo, o capítulo sobre a origem histórica da língua portuguesa, na GPPB, em contraposição ao conhecimento divulgado pela Linguística Histórica, no intuito de evidenciar possíveis rupturas ou continuidades ${ }^{47}$ com essa tradição de estudos. Para tanto, serão apresentados: a proposta de Bagno sobre a origem da língua portuguesa na referida obra; o posicionamento de dez autores que estarão aqui sob a rubrica da Linguística Histórica e, por último, o levantamento de obras do autor em que sobressai posição diversa da assumida por ele na GPPB.

47 Neste artigo, entende-se os termos ruptura, continuidade e descontinuidade considerando a tensão existente entre eles em relação à história, neste caso, da história da origem da língua portuguesa. 


\section{Origem da língua portuguesa: a abordagem da GPPB vs. a abordagem da Linguística Histórica}

A $G P P B$, segundo o próprio autor, foi produzida para alcançar um público específico de estudantes universitários e professores de português, de pedagogia e de outras línguas etc., cujos objetivos fossem de natureza científica. Além disso, a gramática não é, segundo seu autor, um compêndio escolar, pedagógico, destinado a alunos da educação básica, por exemplo, mas um objeto de pesquisa para estudantes ou professores que detêm o mínimo de conhecimento sobre estudos linguísticos e gramaticais.

Bagno (2011) apresenta um olhar particular sobre as questões que envolvem a origem da língua portuguesa, que se distingue da historicamente reconhecida pela Linguística Histórica. Para ele, a língua portuguesa tem origem galega e não latina. No capítulo 5, a GPPB faz uma descrição sincrônica e diacrônica sobre o tema, ou seja, o autor preocupa-se em apresentar historicamente os processos de mudanças que deram origem à língua portuguesa.

Desse modo, a GPPB expõe tanto do ponto de vista linguístico quanto do ponto de vista sócio-histórico testemunhos que retratam "mudanças" ou ao menos ideias em franco desenvolvimento, divulgadas principalmente por grupos de pesquisa da Galiza e de Portugal, como se pode observar nos excertos abaixo, que reforçam as ideias difundidas pelo autor:

O português brasileiro pertence a um grupo de línguas que vamos chamar aqui de portugalego, um nome formado da junção de português e galego as duas línguas mais antigas do grupo, embora a ordem cronológica seja inversa à da formação do nome: primeiro nasceu o galego e do galego nasceu o português. Assim, todas as línguas do grupo são continuações históricas do galego falado no noroeste da Península Ibérica, que por sua vez é resultante do contato linguístico do latim vulgar com a(s) língua(s) céltica(s) que eram faladas ali antes da chegada dos romanos e, eventualmente, com outras línguas das quais não nos sobrou nenhuma notícia" (BAGNO, 2011, p. 202, grifo do autor).

A situação marginalizada do galego decerto contribuiu para que os filólogos portugueses do século XIX não sentissem grande estímulo em reconhecer e assumir a evidência de que o português era e é a continuação histórica da língua galega, levada cada vez mais para o sul, à medida que os reis portugueses expandiam seu território. Não seria digno de um povo soberano e conquistador, responsável pelas aventuras marítimas que revelaram o resto do mundo aos europeus, ter como ancestral uma língua de campônios rudes, uma língua sem prestígio. Daí a designação galego-português. Por isso não é correto, do ponto de vista histórico-geográfico, afirmar, como fazem todas as obras filológicas e 
- | Por que o português não veio do latim?: Uma análise historiográfica da Gramática Pedagógica do Português Brasileiro

gramáticas históricas, que "o português vem do latim". O português vem do galego - o galego, sim, é que representa a variedade de latim vulgar que se constituiu na Gallaecia romana e na Galiza medieval" (BAGNO, 2011, p. 224, grifos do autor) $)^{48}$.

Entretanto, uma análise sobre a origem histórica da língua portuguesa, em materiais de eminentes filólogos e linguistas brasileiros, pode evidenciar a tão propagada origem latina dessa língua, isto é, o reconhecimento, por parte desses autores, de que a maioria das palavras que formam o léxico do português, bem como certas características sintáticas, morfológicas e fonológicas estão presentes no latim que era falado principalmente pelas camadas pobres de Roma e que foi levado para as regiões conquistadas posteriormente.

Nesse sentido, para entender a história do português, é preciso remontar às origens latinas. No caso das línguas românicas, o latim vulgar, de acordo com os pressupostos da Linguística Histórica, é reconhecido como sendo a variedade ${ }^{49}$ que lhes deu origem.

A língua latina, saída da Península Itálica, acompanhou os romanos durante um longo período de conquistas territoriais, instalando-se em partes da Europa, África e regiões da Ásia. Com o passar do tempo e com a fragmentação do Império, transformouse em dialetos distintos que deram origem às línguas românicas, dentre elas, o português.

Em estudos sobre a história da língua portuguesa, diversos autores, reconhecidos na área da filologia e da linguística, têm publicações significativas e de grande circulação que tratam da origem da língua portuguesa. Os autores cujas obras atendem aos requisitos estipulados para a análise nesta pesquisa são:
(i) Said Ali (1908/200850);
(ii) Silva Neto $(1938 / 1946)$;
(iii) Bueno (1955/1967);
(iv) Maurer Jr. (1962);
(v) Elia (1974/1979);
(vi) Bassetto (2001);

\footnotetext{
48 A ideia sobre a origem galega da língua portuguesa é reforçada por Bagno em seu Dicionário crítico de sociolinguística (2017). A citação presente na página 146 do livro não aparece no corpo deste texto pelo fato de ser uma citação à informação presente na página 224 da $G P P B$, já presente neste trabalho.

49 O latim possuía algumas variedades linguísticas, a depender do estrato social de que delas se utilizavam. Entre elas, pode-se mencionar: sermo urbanus, sermo classicus, este se desdobrou em latim eclesiástico e latim profano, e sermo plebeius, modernamente designado de latim vulgar, que se desdobrou em português, galego, castelhano, catalão, provençal, francês, rético, sardo, italiano, dalmático e romeno. Para uma leitura mais aprofundada sobre as variedades do latim, ver Bassetto (2001).

50 Tendo em vista a importância da datação das fontes para um estudo historiográfico e, muitas vezes, da dificuldade de acesso às primeiras edições das fontes selecionadas para a pesquisa, far-se-á, neste artigo, no caso de obras antigas e/ou reeditadas, a citação primeiro da data da publicação original, seguida da data da edição consultada.
} 
(vii) Mattos e Silva (2006);

(viii) Basso e Gonçalves (2014);

(ix) Faraco (2016) e, por último,

(x) Ilari (2018).

A origem latina da língua portuguesa parece ser ponto pacífico em obras consagradas que versam, de algum modo, sobre a temática em foco. Essa questão trazida por eles e, aqui transcrita, explicita claramente uma visão e uma argumentação que reconhece a origem latina da língua portuguesa, constituindo-se, assim, uma tradição ${ }^{51}$ nos estudos histórico-linguísticos.

Said Ali (1908/2008), no já clássico Dificuldades da língua portuguesa, especificamente ao abordar "O purismo e o progresso da língua portuguesa", em conferência realizada na Biblioteca Nacional em 1914, trata do tema da mudança linguística, momento em que também aborda questões de filiação linguística, como se pode ver abaixo:

Não há desdouro no transmutar perene, embora lento, de uma língua. É um fenômeno de vitalidade. Pelas mesmas vicissitudes por que passou a lusitana, passaram também as suas irmãs, as línguas românicas, como todas as outras. $\mathrm{O}$ próprio latim, muito antes de se esgalhar em reto-romano, rumeno, italiano, provençal, francês, espanhol e português já não corria entre o povo com a pureza primitiva (SAID ALI, 2008, p. 207, grifos nossos).

Silva Neto (1938/1946), por sua vez, no que tange à sua produção, sobretudo aquela que se destina ao comentário e descrição do latim vulgar e suas fontes, deixa sobressair em seu texto Fontes do latim vulgar: o appendix probi um estudo crítico que visa constituir uma "História da língua portuguesa" que, no seu desenvolver, apresenta suas ideias sobre a origem latina da língua portuguesa:

Do substrato das línguas românicas deve dizer-se, simplesmente, que foi o latim, o verdadeiro latim, isto é, a língua viva e corrente. Dessa língua real e espontânea a cultura romana criou a língua artística, a língua burilada e lapidada que ainda hoje nos encanta e arrebata (SILVA NETO, 1946, p. 41, grifos nossos).

51 Alonso (2012) desenvolve o conceito de tradição de pesquisa, apresentando-o como uma noção desenvolvida a partir de uma dupla perspectiva. Sobre isso, o autor distingue "a tradição em que se insere o objeto cultural ao qual nos dispusemos a analisar e aquela na qual, como investigadores contemporâneos, estamos inseridos - ambas podem ser ou não coincidentes no tempo e no espaço" (ALONSO, 2012, p. 72). Nos limites desta pesquisa, o conceito de tradição considera o objeto cultural em seu contexto e busca identificar autores e obras com os quais os agentes selecionados nesta pesquisa mantêm relação. 
- Por que o português não veio do latim?: Uma análise historiográfica da Gramática Pedagógica do Português Brasileiro

Bueno (1955/1967) procede a um estudo analítico, em A formação histórica da língua portuguêsa, no intuito de produzir um material que, ao passo em que estudasse a evolução histórica do nosso idioma, desse uma visão panorâmica dessa evolução, assim, a verdadeira transformação do latim vulgar em romance português já era assunto esclarecido e resolvido como se observa nas palavras do autor:

O latim, que penetrou na Ibéria, no século III antes de Cristo, trazido pelas tropas de Cipião, em guerra com Aníbal, pertencia ao tipo vulgar e rústico. Vulgar falariam os comandantes, os escrivães, a gente encarregada da burocracia. Rústico a demais soldadesca, os mesterais que faziam parte das legiões romanas. O latim literário só aparecerá muitos séculos depois quando a Hispânia já podia imitar os modelos de Roma: não só imitar, mas suster o fecho das letras, oferecendo à metrópole os seus poetas, os seus prosadores, os seus filósofos. Celtas e iberos, nessa fusão denominadora celtiberos, tiveram de aprender êste latim rústico, plebeu para elevar-se até aquêle vulgar e polido na escola. Das imperfeições dêste aprendizado idiomático provieram as três línguas românicas da Península: o português, o castelhano e o catalão (SILVEIRA BUENO, 1967, p. 11, grifos nossos).

Maurer Jr. (1962, p. 15, grifo nosso), em seu trabalho O problema do latim vulgar, adota uma postura elucidativa em relação ao seu entendimento sobre a origem latina da língua portuguesa quando reconhece que:

Até o comêço do século XIX pensou-se em geral em um único latim - o dos documentos escritos que nos foram transmitidos pelos autores antigos -, embora alguns espíritos mais lúcidos reconhecessem a existência de um latim do povo inculto, bem diferente daquele e fonte das línguas românicas. Mas foi Frederico Diez quem estabeleceu sôbre bases científicas a origem latina das línguas românicas, demostrando claramente que existia em Roma, ao lado da língua literária, uma língua popular e rústica.

Elia (1974/1979), ao fazer um estudo crítico-comparativo em Preparação à Linguística Românica sobre as línguas românicas, também assinala a origem latina delas quando afirma:

Há porém o latim vulgar encarado precipuamente como base comum das línguas românicas, como o lugar geométrico a que são reconduzidas as chamadas leis fonéticas que descrevem a evolução do latim em neolatim. É o latim entendido como Ursprache (ELIA, 1979, p. 38, grifos nossos). 
Bassetto (2001, p. 87, grifo nosso), em Elementos de Filologia Românica: história externa das línguas, discorre sobre o latim e suas variedades e ressalta as origens das línguas românicas, nos seguintes termos:

É sabido que as línguas românicas provêm do latim; o termo "latim", porém, não é unívoco, já que existem numerosas variedades. Interessa à Filologia Românica particularmente o chamado "latim vulgar", eminentemente falado e, por isso, de reconstituição árdua, mas a verdadeira fonte das línguas românicas. É preciso também saber como essa variedade do latim foi levada a todos os recantos do Império Romano, a documentação existente, além de os fatores que propiciaram o aparecimento de várias línguas a partir desse latim vulgar.

Mattos e Silva (2006, p. 97, grifo nosso), em estudo sobre o período arcaico da língua portuguesa, no livro O português arcaico:fonologia, morfologia e sintaxe, legitima a origem latina da língua portuguesa quando esclarece:

Assim, uma primeira delimitação desta parte do presente livro se define como uma pequena gramática, até certo ponto contrastiva, do português arcaico em relação ao português atual. Além disso, sempre que julgamos essencial, olhamos para o latim, língua que o português, como as demais línguas românicas, continua.

Basso e Gonçalves (2014, p. 35, grifo nosso), em História concisa da língua portuguesa, discorrem sobre a história da língua portuguesa, apresentando suas origens e sua relação estrita com o latim:

Para entender a história do português, será necessário compreender o percurso que o latim trilhou atése diferenciar em línguas românicas, especialmente porque a língua que resultou nas línguas românicas modernas não foi o que chamamos de latim clássico, mas, antes, o latim falado pelas pessoas comuns, no dia a dia, nas mais diversas interações, o chamado latim vulgar.

Faraco (2016, p. 14, grifo do autor), em História sociopolítica da língua portuguesa, também reconhece a origem latina da língua portuguesa:

A língua que designamos atualmente pelo nome de português é o desdobramento histórico dos falares românicos ${ }^{52}$ que se desenvolveram, nos séculos posteriores à dissolução do Império Romano do Ocidente, no noroeste

52 Com o adjetivo românico qualificam-se as línguas que se constituíram como desdobramentos históricos do chamado latim vulgar [...] (grifo nosso) 
- | Por que o português não veio do latim?: Uma análise historiográfica da Gramática Pedagógica do Português Brasileiro

da Península Ibérica, numa área que abrange hoje aproximadamente o norte de Portugal e a Galiza (Comunidade Autônoma da Espanha).

Ilari (2018, p. 27, grifo do autor), em seu livro Linguística Românica, atesta a filiação latina a partir de modificações fonéticas ocorridas em línguas neolatinas, como o português, espanhol, o francês e o italiano, como se vê abaixo:

Quando se comparam, por exemplo, port. e esp. saber, fr. savoir, it. sapere, fica legitimada a conjectura de que sua origem comum tenha sido uma palavra latina (i) cuja primeira sílaba começa por sibilante e (ii) cuja segunda sílaba é tônica, e comporta uma consoante bilabial ou labiodental ( $\mathrm{p}, \mathrm{b}$ ou v). Constatando-se, além disso, que na evolução do latim para o espanhol e o português é regular a passagem do $p$ intervocálico a $b$; que o $p$ intervocálico do latim passa regularmente a $b$ e em seguida a $v$ em francês; que, ainda em francês, o $e$ longo das sílabas tônicas não travadas passou a $e i$, depois oi, oé, ué e wá (a grafia acompanhou esta evolução apenas até a forma oi), torna-se legítimo supor que a forma originária comum fosse *sapére, paroxítona.

O cotejo de trechos das obras desses dez autores poderia ser enriquecido sobremaneira com outros nomes de filólogos e linguistas do cenário internacional, mas a amostra é suficiente para evidenciar os argumentos históricos, geográficos e linguísticos de uma tradição que remonta à primeira metade do século XIX, com Diez e sua tese de que as línguas românicas evoluíram do latim vulgar e não do latim clássico.

Bagno (2011), motivado por questões ideológicas e de política linguística, quer, juntamente com um grupo de pesquisadores da Galiza, instaurar uma tradição diferente, a que entende o português ser oriundo do Galego e não do Latim. Desse modo, a GPPB é a primeira a abordar a tese do galego como a língua que deu origem à língua portuguesa, como se pode constatar adiante na citação de Lagares (2013, p. 343, grifo do autor):

Essa abordagem é superada pela primeira vez na recente Gramática pedagógica do português brasileiro (2012), uma obra que adota explicitamente um "discurso herético" (Bourdieu, 1996) sobre a língua portuguesa no Brasil, e na qual Marcos Bagno afirma que o português não vem do latim [...].

Bagno parece querer imprimir, em sua gramática, aspectos inovadores, que certamente se coadunam com a visão que o autor tem de língua. Especificamente no capítulo cinco, livro II, de sua gramática, Bagno direciona seu discurso para um lugar distinto do que se faz nos estudos tradicionais da Linguística Histórica, articulando o tom do seu discurso em torno de uma aparente ideia de ruptura com a tradição. 
Em relação a isso, pode-se apontar como primeiro elemento a supostamente corroborar essa ideia o título do capítulo, "Do galego ao brasileiro", em que é possível perceber, através do jogo argumentativo do qual o autor se vale, principalmente pelo que está implícito, que, ao suprimir propositalmente o "português" dessa filiação, o autor coloca em evidência a ideia defendida em sua gramática de que o português brasileiro é uma língua plena e independente do português europeu.

Ainda seguindo essa linha de interpretação, pode-se destacar do texto expressões como "grupo portugalego" (BAGNO, 2011, p. 202), "língua materna hegemônica" (ibid., p. 210), "família de línguas derivadas do galego" (ibid., p. 214), que reforçam a sua proposta, pondo em evidência seus argumentos e marcando o seu discurso com um suposto tom de inovação.

Desse modo, seu discurso pode ganhar destaque, na comunidade científica, por conta de valores implícitos na obra, quais sejam: o fato de Bagno ser um linguista que possui representatividade no cenário nacional; ser professor de uma universidade pública de reconhecida importância por toda sociedade e, por fim, por fazer parte de um rol de linguistas preocupados em produzir materiais que, como afirmam Faraco e Vieira (2016, p. 295), cumprem as "demandas pedagógicas de nossa época em se tratando de ensino de língua e gramática".

Outro ponto de particular interesse para essa discussão é o modo como os enunciados são organizados pelo autor, como pode ser observado nos excertos abaixo:

(1) “[...] o português era e é a continuação histórica da língua galega [...]" (BAGNO, 2011, p. 224, grifos nossos);

(2) "Por isso não é correto, do ponto de vista histórico-geográfico, afirmar como fazem todas as obras filológicas e gramáticas históricas, que 'o português vem do latim'" (ibid., grifos nossos);

(3) "O português vem do galego" (ibid., grifo nosso);

(4) “[...] o galego, sim, é que representa a variedade de latim vulgar que se constituiu na Gallaecia romana e na Galiza medieval" (ibid., grifos nossos).

Uma discussão mais específica sobre essa questão volta-se para a assertiva do autor ao justificar, pelo viés histórico e baseado em autores portugueses, que já existia um romance falado da região da Galécia Magna, antes mesmo de o território português existir como tal, o que para Bagno seria mais um forte indicativo de que uma entidade política já existia nesse território galego, logo a designação galego-português para uma língua nessa região seria um equívoco histórico e nas palavras do autor: 
- | Por que o português não veio do latim?: Uma análise historiográfica da Gramática Pedagógica do Português Brasileiro

O termo galego-português foi cunhado como uma espécie de compromisso ideológico entre duas tensões: o reconhecimento de que a língua da poesia medieval era basicamente o galego, e o anseio, de inspiração nacionalista, de incorporar aquela produção literária ao patrimônio cultural do povo português (BAGNO, 2011, p. 222).

Em outro trabalho seu, essa ideia é reforçada seguindo o mesmo pensamento já difundido na GPPB e o autor segue afirmando que "Não parece haver razão por que chamar galego-português uma língua que surgiu 'antes de Portugal, antes do Português', como faz também, por exemplo, o dicionário brasileiro Aurélio [...]" (BAGNO, 2017, p. 145, grifos do autor). Está claro o tom de crítica do autor ao fato de diversas obras, inclusive dicionários antigos e atuais, seguirem confirmando a denominação "galego-português" para designar uma língua falada nesse território. É, pois, a partir desse ponto de vista que o autor constrói seu posicionamento sobre a origem galega do português.

Entretanto, autores da Linguística Histórica, no que tange a esse tema, posicionamse de forma contrária às ideias difundidas por Bagno. Faraco (2016, p. 14), em sua História sociopolítica da língua portuguesa, reconhece o galego-português como uma unidade linguística autêntica daquela região, pois para o referido autor:

Aquele grupo originário de falares românicos do noroeste constituiu a matriz donde emergiram posteriormente o galego e o português modernos. Em razão disso, têm-se usado - desde o surgimento da linguística histórico-comparativa, no século XIX, e, em especial, da romanística (ou filologia românica) e desde a chegada desse novo paradigma científico aos meios acadêmicos de Portugal e Espanha - termos compostos para fazer referência àquele grupo de falares tais como galaico-portugalense, galaico-português, galécio-português, portuguêsgalego ou, mais frequentemente, galego-português.

Ao argumentar a favor do uso independente do termo Galego, Bagno defende, a partir de uma lógica histórica, a anterioridade da entidade político-linguística galega, mas ignora a práxis de uma cultura disciplinar em particular, a linguística histórico-comparativa, como aponta Faraco. Como parece se tratar de um "discurso herético", nada mais conforme do que tanto renegar o termo composto (galego-português) quanto, principalmente, a origem latina do português. O problema não estaria tanto nessa suposta retórica herética, descontínua, em um sentido mais amplo, mas, sim, numa estratégia retórica em que as marcas linguísticas são acionadas para negar a origem latina do português, como no excerto (2), acima transcrito. Dito de outro modo, ao fim e ao cabo, a decisão de Bagno é quanto ao estágio de língua que será eleito para filiação com o Português Brasileiro, para o que ele escolhe o Galego (quanto a esta decisão, não cabe discussão). Mas essa escolha, em absolutamente nada, invalida a tese mais tradicional de que o português vem do latim. Neste caso, o comprometimento genealógico é com um estágio mais recuado no tempo 
e, certamente, menos seguro de um ponto de vista da comprovação empírica, mas daí não se pode concluir, nem histórica, nem linguisticamente, que o português não vem do latim, principalmente a partir do expediente de utilizar enunciados que negam a filiação latina, sejam quais forem as motivações para tal.

No sentido de entender as motivações de Bagno para essa suposta mudança de posicionamento, é importante destacar, ainda, alguns aspectos contextuais. Em 2006, viajou à Galiza, a convite do linguista galego Henrique Monteagudo, para ministrar cursos sobre o português brasileiro no Mestrado da Universidade de Santiago de Compostela na área de Filologia Galega e Portuguesa. A partir daí, travou os primeiros contatos com a língua galega e com obras que retratavam a história da língua galega e, consequentemente, da origem histórica da língua portuguesa vinculada a ela.

O tempo que passou na Galiza parece ter permitido que o autor aprofundasse o que já sabia sobre a história da língua portuguesa, principalmente, no que diz respeito à sócio-história da Galiza. É, portanto, a amizade com Monteagudo e as leituras com as quais travou contato que, provavelmente, propiciaram-lhe uma aproximação com as ideias em voga.

Observa-se, portanto, que a intenção do autor, em sua gramática, era colocar em evidência uma nova maneira de conceber a história da origem da língua portuguesa e brasileira, que levasse em conta, não a autonomia e a hegemonia de Portugal, mas, sim, a história social e política da sociedade Galega.

Entretanto, um breve retrospecto das publicações de Bagno, mais detidamente no período de 1997 a $2014^{53}$, permite que se chegue a um número de doze ${ }^{54}$ obras publicadas, voltadas para área da linguística e suas subáreas, em que predominam a temática de estudos sobre o português brasileiro e nas quais é possível observar outro posicionamento do autor, no que se refere à história da língua portuguesa.

Levando-se em conta que toda essa produção selecionada foi analisada na totalidade, pode-se, a partir disso, tecer algumas considerações importantes a fim de entender a importância que o autor dá para o conhecimento histórico em suas produções. Quando analisados os títulos e o conteúdo de cada livro, foi possível observar que Bagno, independentemente do conteúdo abordado (preconceito linguístico, livro didático, gramática, pesquisa em linguística etc.), em todos eles, e, de algum modo, faz remissão à origem histórica da língua portuguesa. Interessante destacar, antes de mais nada, que tais referências, em todas as obras selecionadas, mesmo aquelas impressas após a publicação da $G P P B$, indicam uma postura distinta daquela que o autor apresenta em sua gramática.

53 Só foram compulsadas as obras produzidas por Bagno da área da linguística.

54 O quadro 3 não apresenta exemplo do livro Gramática de bolso do português brasileiro (2013) por ser uma obra resumida da $G P P B$. 
- Por que o português não veio do latim?: Uma análise historiográfica da Gramática Pedagógica do Português Brasileiro

No que interessa para esta discussão, cabe sintetizar as ideias principais do autor em destaque quanto a esses períodos em que suas publicações confirmam um posicionamento distinto do que apresenta na $G P P B$.

O primeiro título que compõe o rol de obras do autor é $A$ Língua de Eulália: novela sociolinguística, publicada no ano de 1997. Nela o autor reconhece a origem latina da língua portuguesa, como se pode observar a seguir:

Recorrer à história da língua é uma tentativa que faço de mostrar que a língua portuguesa, em todas as suas variedades, continua em transformação, continua mudando, caminhando para as formas que terá daqui um tempo. Da mesma maneira como o latim foi se transformando lentamente até resultar nas diversas línguas românicas hoje existentes - italiano, romeno, romanche, francês, provençal, sardo, catalão, espanhol, português -, também cada uma delas continua a se transformar (BAGNO, 2006, p. 35).

Na obra, Pesquisa na escola: o que é, como se faz, publicada no ano de 1998, sobressai, também, a tese sobre a origem latina da língua portuguesa quando este diz: "Por isso o latim luna deu lua em português, e o verbo volare deu o nosso voar" (BAGNO, 2010a, p. 68, grifos do autor).

Em o Preconceito linguístico: o que é, como se faz, obra publicada em 1999, tem-se o seguinte:

Afinal, se não fosse desse modo, ainda estaríamos falando latim... Na verdade, falamos latim, um latim que sofreu tantas transformações que deixou de ser latim e passou a ser português. Da mesma forma, o português do Brasil - queiram os gramáticos ou não - também está se transformando, e um dia, daqui a alguns séculos será uma língua diferente da falada em Portugal - mais diferente do que já é (BAGNO, 2007a, p. 98, grifos do autor).

A quarta produção de Bagno intitula-se Dramática da língua portuguesa: tradição gramatical, mídia e exclusão social, e foi publicada em 2000. Para dar conta da origem da língua portuguesa, o autor se posiciona na obra do seguinte modo:

Ao contrário, porém, das teorias nacionalistas do século XIX, em que se propunha considerar que, assim como as línguas românicas 'saíram' do latim, o português do Brasil 'saiu' do português de Portugal, é necessário propor uma deriva dupla, iniciada no século XVI: do latim surgiu um tronco chamado português que, a partir de 1500, se bifurcou em outros dois troncos, o brasileiro e o europeu, cada qual seguindo seu curso, sofrendo mudanças em direções 
e ritmos diferentes um do outro. Assim talvez se possa demonstrar o mito de que os portugueses falam "certo" desde que o mundo é mundo, mantendo intacta e pura sua língua, enquanto os brasileiros, que receberam essa língua de "empréstimo", têm desde sempre maltratado, corrompido e estropiado ela (BAGNO, 2000, p. 273, grifos do autor).

Na obra, Português ou brasileiro? Um convite à pesquisa, cujo ano de publicação é 2001, o autor segue alinhado com a mesma tese:

O que representou esse processo de seleção de regras gramaticais e de criação de um modelo de língua? Representou um corte, uma interrupção artificial do fluxo natural da língua, um desvio de seu curso e uma imobilização de sua dinâmica. Vamos imaginar que a língua portuguesa é um rio, que se formou como um defluente (isto é, um braço) de outro rio, que é o latim: os outros braços que partem do latim são as demais línguas da família românica (italiano, romeno, francês, espanhol, etc.) (BAGNO, 2004, p. 47-48).

A sexta produção de Bagno é A norma oculta: língua \& poder na sociedade brasileira, publicada no ano de 2003. Nela o autor igualmente confirma a tese da origem latina da língua portuguesa quando afirma:

Podemos comparar o surgimento dessas inovações mais radicais nas variedades estigmatizadas do português brasileiro com o que ocorreu - em escala muito maior e muito mais radical, é claro - no processo de formação da própria língua portuguesa e das demais línguas derivadas do latim, como o francês, o espanhol, o italiano, o romeno etc. (BAGNO, 2003, p. 136).

A sétima obra, Nada na língua épor acaso: por uma pedagogia da variação linguística, publicada em 2007, numa linha de continuidade, também se compromete com a tese referida:

Outro efeito de relatinização do português no período renascentista foi a chamada recondução de diversas palavras a uma forma mais próxima do étimo latino. Muitos vocábulos, depois de passar pelos processos de mudança regulares do português, tinham ficado muito diferentes do termo latino do qual se originavam. Considerando isso um "problema", e sempre desejosos de aproximar sua língua o máximo possível do latim, os gramáticos e literatos da época impuseram novas formas para substituir as formas tradicionais na língua, que vinham sendo usadas desde os primórdios do idioma (BAGNO, 2007b, p. 93). 
- Por que o português não veio do latim?: Uma análise historiográfica da Gramática Pedagógica do Português Brasileiro

No livro, Não é errado falar assim! em defesa do português brasileiro, publicado em 2009, o autor explica, a partir da tese da deriva, modificações de natureza vocálica do latim para algumas línguas neolatinas:

As mudanças linguísticas não ocorrem aleatoriamente. Vamos ver um exemplo: O ditongo latino au se transformou, em algumas línguas derivadas do latim, na vogal simples $o$. Assim, a palavra latina paucu- está na origem do italiano e do espanhol poco e do português pouco (que pronunciamos pôcu) Por que o au se transformou em $o$, e não em $e$, em $i$, em ão etc.? Porque essa transformação já estava, por assim dizer, prevista, "embutida" no próprio sistema dos sons da língua (BAGNO, 2009a, p. 42, grifos do autor).

Na nona obra analisada, Gramática: passado, presente e futuro, publicada no ano de 2009, o autor explicita seu posicionamento quanto à origem da língua portuguesa do seguinte modo:

$\mathrm{Na}$ transformação das variedades do latim popular coloquial (chamado tradicionalmente de "vulgar") nas diferentes línguas românicas (galego, português, espanhol, francês, catalão, provençal, italiano, romeno etc.) (BAGNO, 2009b, p. 95).

$\mathrm{Na}$ décima obra selecionada, intitulada Gramática, pra que te quero? os conhecimentos linguísticos nos livros didáticos de português, publicada no ano de 2010, também é possível reconhecer a posição do autor quanto à origem da língua portuguesa, quando ele afirma que:

À medida que o tempo avançou, desapareceram os falantes nativos de latim ou, mais precisamente, o latim vulgar se transformou nos diferentes romances (palavra derivada de Roma, pátria da língua latina) que, muito mais tarde, se transformariam nas diferentes línguas românicas. O latim (clássico) sobreviveu unicamente nas mãos das (poucas) pessoas que liam e escreviam em latim, mas que eram falantes de outras línguas maternas - monges, em sua grande maioria, especialmente beneditinos (BAGNO, 2010b, p. 92, grifos do autor).

Como já se disse, é somente na Gramática pedagógica do português brasileiro, publicada em 2011, que Bagno (2011, p. 224) apresenta a 'nova' tese:

A situação marginalizada do galego decerto contribuiu para que os filólogos portugueses do século XIX não sentissem grande estímulo em reconhecer e assumir a evidência de que o português era e é a continuação histórica da língua 
galega, levada cada vez mais para o sul, à medida que os reis portugueses expandiam seu território. Não seria digno de um povo soberano e conquistador, responsável pelas aventuras marítimas que revelaram o resto do mundo aos europeus, ter como ancestral uma língua de campônios rudes, uma língua sem prestígio. Daí a designação galego-português. Por isso não é correto, do ponto de vista histórico-geográfico, afirmar, como fazem todas as obras filológicas e gramáticas históricas, que "o português vem do latim". O português vem do galego - o galego, sim, é que representa a variedade de latim vulgar que se constituiu na Gallaecia romana e na Galiza medieval.

A partir da tese defendida na $G P P B$, era se esperar a manutenção dela nas produções subsequentes, mas, por exemplo, no livro Sete erros aos quatro ventos: a variação no ensino de português, publicada em 2013, o que se tem é o retorno à tese da origem latina:

Em primeiro lugar, é preciso lembrar que o português é derivado do latim vulgar, isto é, do latim falado pelo povo, pelos soldados romanos que dominaram a Península Ibérica, onde fica Portugal ${ }^{55}$ (BAGNO, 2013, p. 168, grifo do autor).

Por fim, a décima terceira obra analisada é Língua, linguagem, linguística: pondo os pingos nos ii, publicada no ano de 2014. Nela também, tem-se um retorno à tese latina:

É isso que explica, então, as diferenças marcantes, por exemplo, entre as diversas línguas surgidas do latim imperial: português, galego, castelhano, catalão, francês, provençal, sardo, piemontês, lombardo, vêneto, toscano, napolitano, romeno etc. Em cada uma das regiões conquistadas por Roma, o latim passou a ser falado por povos que, antes, empregavam outras línguas e que transferiram hábitos linguísticos ancestrais à nova língua que passaram a falar (BAGNO, 2014, p. 91).

Quando comparado o posicionamento que Bagno apresenta, sobre a origem da língua portuguesa, nas obras acima referenciadas e seu posicionamento na $G P P B$, verificase um discurso contraditório. Observe-se que o autor começa a afastar-se da perspectiva tradicional da Linguística Histórica e, concomitante a isso, passa a adotar uma perspectiva historiográfica divulgada por estudos galegos e portugueses. Contudo, sua produção não

55 Esse exemplo, retirado do livro Sete erros aos quatro ventos: a variação linguística no ensino de português, não foi escrito por Bagno. Faz parte de uma citação apresentada pelo autor, retirada de um dos livros didáticos do qual faz análise. No entanto, consta como exemplo, primeiro, por fazer referência à origem da língua portuguesa, segundo, pelo fato de o autor concordar com o que escrevem as autoras, visto que em parágrafo anterior à citação no texto afirma "É por isso que, individualmente, há obras que se destacam, principalmente no eixo dos conhecimentos linguísticos, por oferecerem, em diversos momentos, um trabalho bastante adequado na perspectiva do que venho chamando aqui de educação linguística [...] insisto, apresentam qualidades suficientes para terem sido aprovadas no processo de avaliação" (BAGNO, 2013, p. 168, grifos do autor). 
- | Por que o português não veio do latim?: Uma análise historiográfica da Gramática Pedagógica do Português Brasileiro

acompanha a mudança de suas ideias e pesquisas, como pode ser confirmado pelos exemplos supra.

Ora, se em uma obra que, claramente, pretende ser um marco na produção do autor, haja vista que além de ser a primeira gramática produzida por ele, distingue-se, em muitos aspectos, das outras gramáticas igualmente publicadas neste início de século, parece contraditório o fato de suas produções subsequentes não seguirem uma suposta proposta inovadora.

É interessante observar que o posicionamento distinto que Bagno apresenta pode indicar que, mesmo compartilhando com os estudos galegos e portugueses uma concepção histórica de que a língua portuguesa tem origem no galego, os estudos tradicionais, amplamente divulgados por ele antes de travar contato com essa "nova" forma de olhar os fatos da língua, com efeito, ainda parecem ter força e forma no discurso do autor, uma vez que, em materiais produzidos posteriormente à publicação da $G P P B$, o autor volta a asseverar que o português vem do latim. Os materiais posteriores à $G P P B$ não deveriam confirmar suas hipóteses? Aparecer em sua gramática não seria suficiente para garantir uma mudança de posicionamento? Tais questionamentos podem evidenciar que a discussão sobre a origem da língua portuguesa, nesse contexto, parece estar mais voltada para interesses de cunho político-ideológico do que propriamente linguístico já que outros materiais, que não podem ser desconsiderados tendo em vista sua importância histórica, fundamentam, com base em diversos princípios, a origem latina do português.

\section{Considerações finais}

Este artigo discutiu o tratamento dado à origem da língua portuguesa na $G P P B$ e em outras vinte e três obras no intuito de, com base em um argumento que se faz científico, problematizar sobre a filiação genealógica do português a partir da tese defendida por Bagno na GPPB. Levando-se em conta as análises empreendidas no decorrer do artigo, há que se mencionar que, em relação às fontes secundárias, especificamente dos autores ditos tradicionais, a tese comum é a de que o português é uma língua originada do latim vulgar, assim como outras línguas da família românica. Além disso, as outras fontes secundárias, aquelas produzidas e publicadas por Bagno, no período de 1997 a 2014, também oportunizaram observar que predominou, em todas elas, o posicionamento do autor ao reconhecer a origem latina da língua portuguesa. No caso da fonte primária, predominou uma tese diferente, a de que o galego é a origem de diversas línguas como o português europeu e o português brasileiro.

No que toca à posição de Bagno em diferentes momentos de sua produção, foi possível observar que o autor muda pontualmente a forma como concebe a origem histórica da língua portuguesa, na GPPB, adotando, para tanto, um discurso aparentemente de ruptura em relação à tradição. 
Entretanto, no caso das fontes secundárias, relativas às produções de autor, predominou um discurso de continuidade em relação ao discurso tradicional.

Em síntese, essas constatações gerais tendem a sugerir que o movimento de descontinuidade encontra-se bastante relativizado na produção de Bagno, isto é, apresentase mais relacionado à descrição de um fenômeno linguístico e histórico em um contexto e em uma obra específica do que a uma efetiva mudança de posicionamento.

Por fim, os dados colhidos podem sugerir que a adoção de um suposto discurso de ruptura, na GPPB, não foi suficiente para que Bagno promovesse mudanças "radicais", pelo menos no que se refere à origem da língua portuguesa, em suas produções. Retomando, pois, a pergunta feita no título deste artigo, juntamente com as reflexões aqui sugeridas, talvez as escolhas retórico-argumentativas de Bagno na defesa na "nova" tese sejam seu calcanhar de Aquiles e, ao fim, ele não possa responder negativamente à pergunta, haja vista que ele mesmo responde a ela positivamente, concordando com a tese tradicional, em produções pós $G P P B$.

\section{Referências}

ALONSO, M. C. Multidimensionalidad, Complejidad y Dinamismo en la historiografía linguística y en su definición del concepto tradición. Todas as letras. v. 14, n. 1, p. 71-86, 2012. <http://editorarevistas.mackenzie.br/index.php/tl/.../3495>. Acesso em: 09 fev. 2016.

BAGNO, M. A. Dramática da língua portuguesa: tradição gramatical, mídia e exclusão social. São Paulo: Loyola, 2000.

BAGNO, M. A. A norma oculta: língua e poder na sociedade brasileira. São Paulo: Parábola Editorial, 2003.

BAGNO, M. A. Português ou brasileiro?: um convite à pesquisa. 4. ed. São Paulo: Parábola Editorial, 2004.

BAGNO, M. A. A Língua de Eulália: novela sociolinguística. 15. ed. São Paulo: Contexto, 2006.

BAGNO, M. A. Preconceito linguístico: o que é, como se faz. 49. ed. São Paulo: Loyola, 2007a.

BAGNO, M. A. Nada na língua é por acaso: por uma pedagogia da variação lingüística. São Paulo: Parábola Editorial, 2007b. 
- | Por que o português não veio do latim?: Uma análise historiográfica da Gramática Pedagógica do Português Brasileiro

BAGNO, M. A. Não é errado falar assim! em defesa do português brasileiro. São Paulo: Parábola Editorial, 2009a.

BAGNO, M. A. Gramática: passado, presente e futuro. Curitiba: Aymará, 2009b

BAGNO, M. A. Pesquisa na escola: o que é, como se faz. 24. ed. São Paulo: Loyola, 2010a.

BAGNO, M. A. Gramática, pra que te quero? os conhecimentos linguísticos nos livros didáticos de português. Curitiba: Aymará, 2010b.

BAGNO, M. A. Gramática pedagógica do português brasileiro. São Paulo: Parábola Editorial, 2011.

BAGNO, M. A. Sete erros aos quatro ventos: a variação no ensino de português. São Paulo: Parábola Editorial, 2013.

BAGNO, M. A. Língua, linguagem, linguística: pondo os pingos nos ii. São Paulo: Parábola Editorial, 2014.

BAGNO, M. A. Dicionário crítico de sociolinguística. São Paulo: Parábola Editorial, 2017.

BARROS, J. D'A. Fontes Históricas: revisitando alguns aspectos primordiais para a Pesquisa Histórica. Mouseion, n. 12, p. 129-159, 2012.

BASSETTO, B. F. Elementos de filologia românica: história externa das línguas. São Paulo: Editora da Universidade de São Paulo, 2001.

BASSO, R. M.; GONÇALVES, R. T. História concisa da língua portuguesa. Petrópolis: Vozes, 2014.

BASTOS, N. B.; PALMA, D. V. (Orgs.). História Entrelaçada 3: a construção de gramáticas e o Ensino de Língua Portuguesa na segunda metade do século XX. Rio de Janeiro: Nova Fronteira, 2008.

BATISTA, R. de O. Retórica de ruptura e descontinuidade nas ciências da linguagem: um estudo pela historiografia da linguística. Confluência. Rio de Janeiro. n. 48, p. 119-141, $2^{\circ}$ sem. 2015.

BECHARA, E. Moderna gramática portuguesa. 37. ed. Rio de Janeiro: Nova Fronteira, 1999. 
BORGES NETO, J. Gramática do português brasileiro. In: FARACO, C. A.; VIEIRA, F. E. Gramáticas brasileiras: com a palavra, os leitores. São Paulo: Parábola Editorial, 2016.

BUENO, F. da S. A formação histórica da língua portuguêsa. 3. ed. São Paulo: Saraiva, 1967[1955].

CASTILHO, A. T. de. Nova gramática do português brasileiro. São Paulo: Contexto, 2010.

ELIA, S. Preparação à lingüística românica. 3. ed. Rio de Janeiro: Ao Livro Técnico, 1979.

FARACO, C. A. História sociopolítica da língua portuguesa. São Paulo: Parábola Editorial, 2016.

FARACO, C. A.; VIEIRA, F. E. (Org.). Gramáticas brasileiras: com a palavra, os leitores. São Paulo: Parábola Editorial, 2016.

ILARI, R. Linguística Românica. 2. ed. São Paulo: Contexto, 2018.

KOERNER, E. F. K. Quatro décadas de Historiografia Linguística: estudos selecionados. Centro de Estudos em Letras: Universidade de Trás-os-Montes e Alto Douro, 2014.

LAGARES, X. C. O galego e os limites imprecisos do espaço lusófono. In: LOPES, L. P. da M. (Org.). O português no século XXI: cenário geopolítico e sociolinguístico. São Paulo: Parábola Editorial, 2013.

LEITE, M. Q. Tradição, invenção e inovação em gramáticas da língua portuguesa - séculos XX e XXI. In: NEVES, M. H. de M.; CASSEB-GALVÃO, V. C. Gramáticas contemporâneas do português: com a palavra, os autores. São Paulo: Parábola Editorial, 2014.

MATTOS E SILVA, R. V. O português arcaico: fonologia, morfologia e sintaxe. São Paulo: Contexto, 2006.

MAURER JR., T. H. O problema do latim vulgar. Rio de Janeiro: Livraria Academica, 1962.

MULINACCI, R. Moderna gramática portuguesa: habemus grammaticam?. In: FARACO, C. A.; VIEIRA, F. E. Gramáticas brasileiras: com a palavra, os leitores. São Paulo: Parábola Editorial, 2016. 
- Por que o português não veio do latim?: Uma análise historiográfica da Gramática Pedagógica do Português Brasileiro

NEVES, M. H. de M.; CASSEB-GALVÃO, V. C. (Org.). Gramáticas contemporâneas do português: com a palavra, os autores. São Paulo: Parábola Editorial, 2014.

SAID ALI, M. Dificuldades da língua portuguesa. 7. ed. Rio de Janeiro: ABL: Biblioteca Nacional, 2008.

SILVA NETO, S. da. Fontes do latim vulgar: o apêndix probi. 2. ed. Rio de Janeiro: Imprensa Nacional, 1946[1938].

SWIGGERS, P. La historiografía de la linguística: apuntes y reflexiones. Revista argentina de historiografia lingüística, v. I, n. 1, p. 67-76, 2009.

VIEIRA, F. E. Gramáticas brasileiras contemporâneas do português: linhas de continuidade e movimentos de ruptura com o paradigma tradicional de gramatização. 2015. 476 f. Tese (Doutorado em Linguística) - Centro de Artes e Comunicação, Universidade Federal de Pernambuco, Recife, 2015.

VIEIRA, F. E. Gramatização brasileira contemporânea do português: novos paradigmas?. In: FARACO, C. A.; VIEIRA, F. E. Gramáticas brasileiras: com a palavra, os leitores. São Paulo: Parábola Editorial, 2016.

COMO CITAR ESTE ARTIGO: ANJOS, Marcelo Alessandro Limeira dos; OLIVEIRA, Meryane Sousa. Por que o português não veio do latim?: Uma análise historiográfica da gramática pedagógica do português brasileiro. Revista do GEL, v. 15, n. 2, p. 61-84, 2018. Disponível em: https://revistadogel.gel.org.br/

DOI: $\underline{\text { http://dx.doi.org/10.21165/gel.v15i2.2126 }}$

Submetido em: 13/07/2018 | Aceito em: 02/10/2018 